\title{
Learning from COVID-19: the role of architecture in the experience of urban landscapes
}

Marta Rodríguez Iturriaga

Department of Architectural Construction, University of Granada, Spain

miturriaga@ugr.es

\begin{abstract}
The COVID-19 pandemic, through lockdowns and mobility restrictions, has created an atmosphere of global reflection towards contemporary urban landscapes. Architecture is an essential component in them and determines, to a large extent, how building users perceive, interpret, and value the surrounding environment. From an experiential and phenomenological perspective, and taking into account the situations lived in 2020, the paper explores the existing relations between architecture and urban landscape at three levels: first, the experience of the environment from the architectural space - namely, the home -; second, the experience of the interior urban landscape' at street level; and finally, the experience of the 'exterior urban landscape' from city fringes or vantage points that provide vast prospects. The article advocates a holistic understanding of landscapes in building and urban design processes and suggests landscape architecture can offer a valuable apprenticeship in this sense. A sustained interplay between those disciplines shaping the built environment is decidedly needed. The paper concludes by pointing out that landscape, given its integrating and all-encompassing condition, could articulate the entire set of municipal urban policies through a transdisciplinary 'city-landscape' plan.
\end{abstract}

\section{Keywords}

Urban Landscape, Architecture, Experience of Landscape, Existential Space, City-landscape 


\section{Introduction}

The COVID-19 crisis is sparking debates on central everyday-life aspects that before were scarcely considered or indefinitely postponed. The impact of human settlements on nature or the technological updating of activities such as communication, teaching, working, and leisure are some of the most evident. Moreover, mobility restrictions and prolonged stays at home during lockdowns have naturally drawn attention to an issue frequently overlooked, both from administrations and planning and design practitioners. Unexpectedly, the global situation has raised a clamorous question: Are the urban landscapes we inhabit satisfying?

Urban landscape quality is increasingly associated with place experience rather than merely aesthetics or scenic beauty (Thayer, 1989; Council of Europe, 2000; Thwaites, 2001). Numerous features determine the experience of urban landscapes. However, from a spatial point of view, we can basically distinguish between mass and void. Both are experienced simultaneously in the urban environment, although different professionals are generally in charge of their design - mainly architects and landscape architects (Eckbo, 1983). This text will focus on architecture, the solid or built part of the urban space, due to the author's training. Nevertheless, we will soon realize that a quality urban landscape requires an integrated design of buildings and open spaces. In addition, we will notice that landscape architecture presents some epistemological and creative approaches whose assimilation would enrich the professional positions of other disciplines towards the lived environment. Learning from landscape architecture would also help reduce the pressures usually acting on building and planning processes that have proven detrimental to the quality of the urban landscape.

The contribution of architecture to any urban landscape comprises both physical and interpretive aspects. Regarding the first, it is clear that an architectural work perceived from the outside, being a material, formal, functional, and energetic object of significant scale, always nuances the site in an objective way. From the inside, architecture also materially establishes the points and areas of connection between the interior and the exterior, filtering stimuli and allowing or banning view and movement. The influence of architecture on the landscape interpretative level is less obvious but equally decisive. Firstly, architecture evinces the cultural understanding of the urban and territorial context by the society considered (Lewis, 1979), giving form and material expression to the relations desired to establish with the surrounding environment. The historical tendency to build/inhabit (Heidegger, 
[1951] 1994) in a certain way in a particular territory is increasingly known as Baukultur (European Ministers of Culture, 2018). From this point of view, architecture appears as a reflection or material crystallization of the impressions, appreciations, and expectations of a social group regarding its geographical context. But apart from reflecting an already-existing social consideration of the territorial setting, architecture also plays an active role in the forge and consolidation of cultural approaches towards it. Through experience, architecture provides the spatial frame for everyday existence, proposing and spreading readings of the city and the territory beyond. In other words, architectural constructions not only fix numerous aspects of the daily interaction with urban spaces but also directly condition how users perceive, interpret, and value the surrounding environment.

This double transformative capacity entails a big social responsibility: architecture can banalize the context, induce disaffection and place consumption, or favor wellbeing, strengthen collective identity, increase territorial heritage awareness, and promote nature respect. Far from being innocuous, these attitudes, when extended, can change public demands and consequently reorient urban policies and business approaches; these, in turn, bring about transformations that tend to intensify some readings of the environment and obliterate others, thus completing the circular process. In a restricted-mobility situation, with local inhabitants as the only users and perceivers of urban landscapes, a reflection on how architecture is molding their life experience in connection with the environment appears more convenient than ever, and this paper intends to be an invitation in this sense.

Christian Norberg-Schulz considered architecture the first level of existential space, followed by the city and then by the landscape, in an overlapping growing
As Edward Relph noted, existential space is intersubjective, hence, potentially shared by all members of a social group (1976, p. 12). That means the experience of the environment is subject to cultural and idiosyncratic features that make it at least partly independent of individual subjectivity. Basing on these considerations, in the wake of the COVID-19 pandemic, it seems necessary to reexamine the existing relations between architecture and urban landscape at three levels.

\section{‘Homescapes': The Experience of Dwelling}

First, we should consider the experience of the environment from the architectural space. A home is in itself a domestic micro-landscape of architectural scale (Cullen, [1961] 1981, p. 28) that filters and introduces fragments of the larger landscape around. It is the first and most determining 'shell' (Bachelard, [1957] 2013, pp. 140-170) in the interaction with the environment (natural, built, and social), and it prefigures in a great deal the attitude its dwellers will adopt towards the exterior world. Phenomenologically, architectural space and the perceptible surroundings invariably overlap in an experiential continuum (Neutra, 1955, p.13; Fitch, 1965; Holl, [1994] 2011, p.15). As a result, the actual 'lived space' (Merleau-Ponty, [1945] 1993) not only includes the home interior but virtually extends to the sky, the horizon, and the surrounding areas, up to the limits of multisensory perception (Fig. 1). In this sense, a room can be physically small but become almost endless because of the qualified and ever-changing experience of the world it provides. 'Prospect and refuge', as postulated by Jay Appleton (1975), still synthesize the phenomenological essence of the ideal home. All these considerations lead us to characterize the experience of the landscape from the architectural space as liminal, transitional, dialectic, intimate, static, and receptive.

It, therefore, seems evident that reducing residential projects to the routine design of interior rooms 
Fig. 1 - The experience of dwelling, between the room and the landscape (author copyrights). implies disregarding the other indispensable component in the experience of dwelling: the environment. This year, the pandemic has shown that obviating the quality of the relations between inside and outside and the presence of adequate exterior spaces, regardless of the comfortability of the interior ones, has forced a substantial part of the population to face lockdown in adverse conditions, exposing them to physical and mental disorders, isolation and depression (Fig. 2). However, those inhabiting high-quality environments and benefiting from generous windows and transitional spaces - such as gardens, patios, terraces, balconies, or communal open yards, where contact with the natural elements was possible - have confronted this challenge more easily. The positive effects are the instant psychological relief, the minor feeling of seclusion, the more activities allowed, and the comforting sense of belonging to a broader living system - community, neighborhood, town, region, or simply planet Earth.

The public recognition of this reality has radically altered user preferences, prioritizing sun, light, air, na-

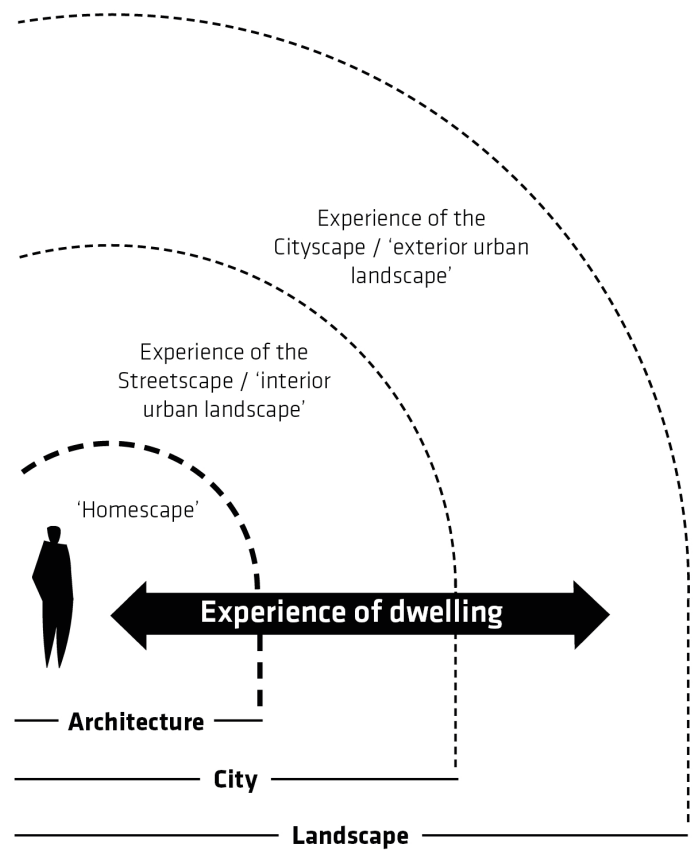

ture, and views over proximity to work and central areas (Aranda, 2020; Barnés and Sanz, 2020). These changes in demand have, in turn, had a noticeable impact on the real estate sector, resulting in a renewed preference for single-family homes in suburban locations (Batty, 2020; Ferrás Sexto, 2020). Surprisingly, while one could imagine that, in this context of forced social distancing, the exponential increase in the use of digital environments might be favoring a deterritorialization of everyday life, thus making the quality of the actual surroundings almost irrelevant, this aprioristic intuition turns out to be only partially true. We are witnessing a growing deterritorialization of work and social relations, but not of dwelling. The widespread moving of teleworkers to warm coastal areas or rural inland enclaves is sufficiently representative (Hermann and Paris, 2020; Putinja, 2021). The quality of the lived environment does matter; in fact, it matters more than ever (Alraouf, 2021).

Although the pandemic will be temporary, it has already introduced structural changes in working, 


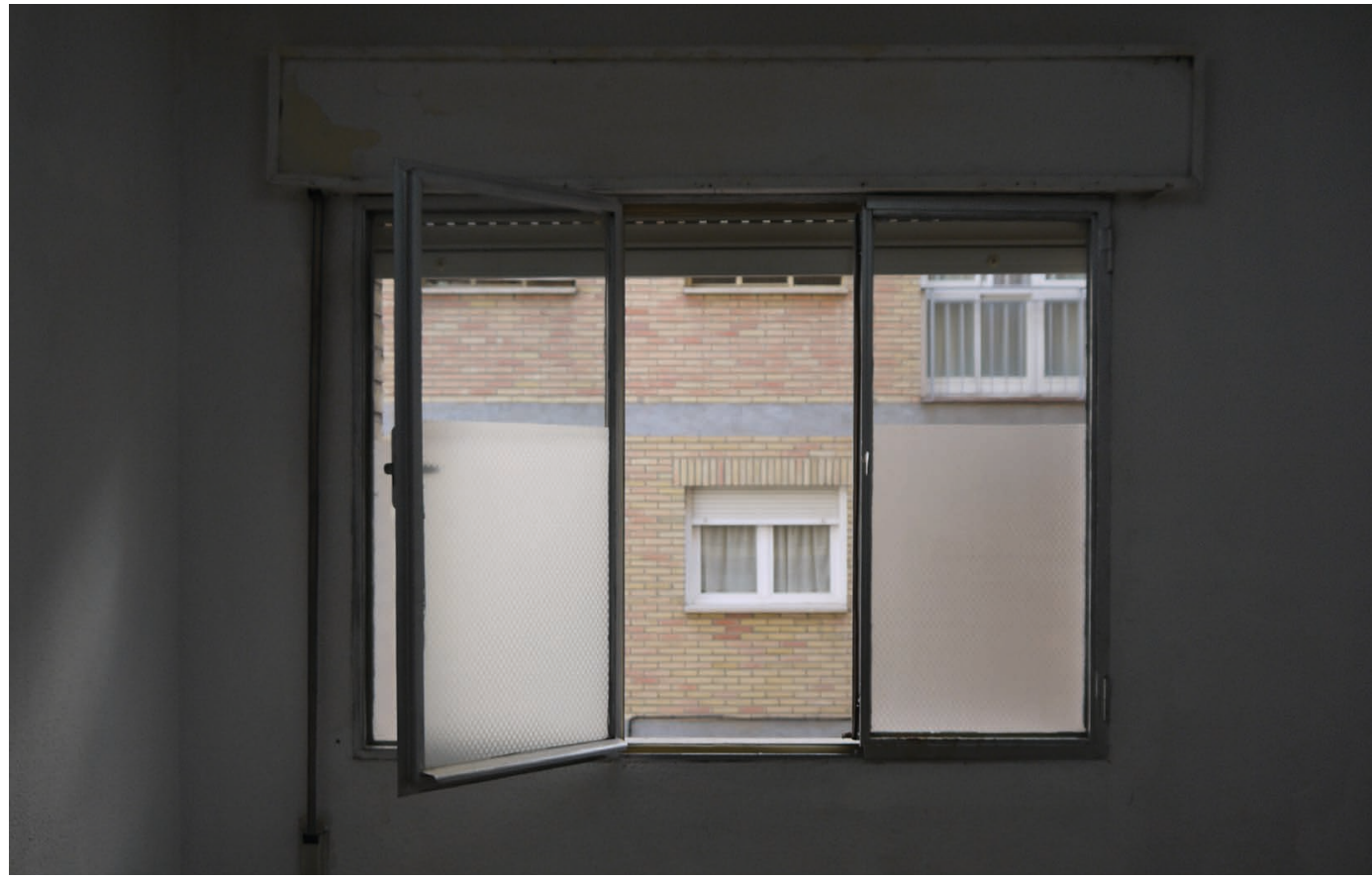

Fig. 2 - View from the window of a typical residential building from the 60s in Granada (Spain). The awkward perspective and the threat to privacy have led to veiling the lower half of the glass (author copyrights).

learning, and enjoying free time that are here to stay, being the expansion of virtual activities perhaps the most apparent. These novelties imply a more intensive use of the home, which is no longer understood as a simple night shelter but becomes a classroom, office, study room, or gym at different times. To adequately host these functions, a comforting link to the outside world has proved to be desirable, in addition to the obvious spatial flexibility. Besides, now that many of us have experienced the impossibility to leave home, it seems opportune to remember those collectives with permanent or transitory limited mobility due to illness, age, or childcare, whose psychological needs also have to be met. Architects should integrate the experience of the environment in new housing, office, sanitary or educational projects - to cite just some of the activities which involve
The views of street life, the horizon, and the contact with nature are the most valued aspects, as research has repeatedly shown (Lynch, 1960; Markus, 1967; Kaplan, 1983; Kaplan and Kaplan, 1989; Kaplan, 2001; Kearney, 2006; Mirza, 2015; Cuerdo-Vilches et al., 2020). Significantly, in 2020 there have been numerous cultural initiatives to liven up the lockdowns that have invited people to take photographs from their windows ${ }^{1}$. This abundant graphic material offers an unprecedented possibility of drawing territorialized conclusions on the existing residential park. Some authors have already addressed a housing inquiry during the pandemic, though not specifically focusing on the experience of the environment provided (CuerdoVilches et al., 2020). Pending systematic research in this regard, it is already evident that our cities are full of unimaginative buildings whose windows and narrow terraces are mechanically set, poor- 


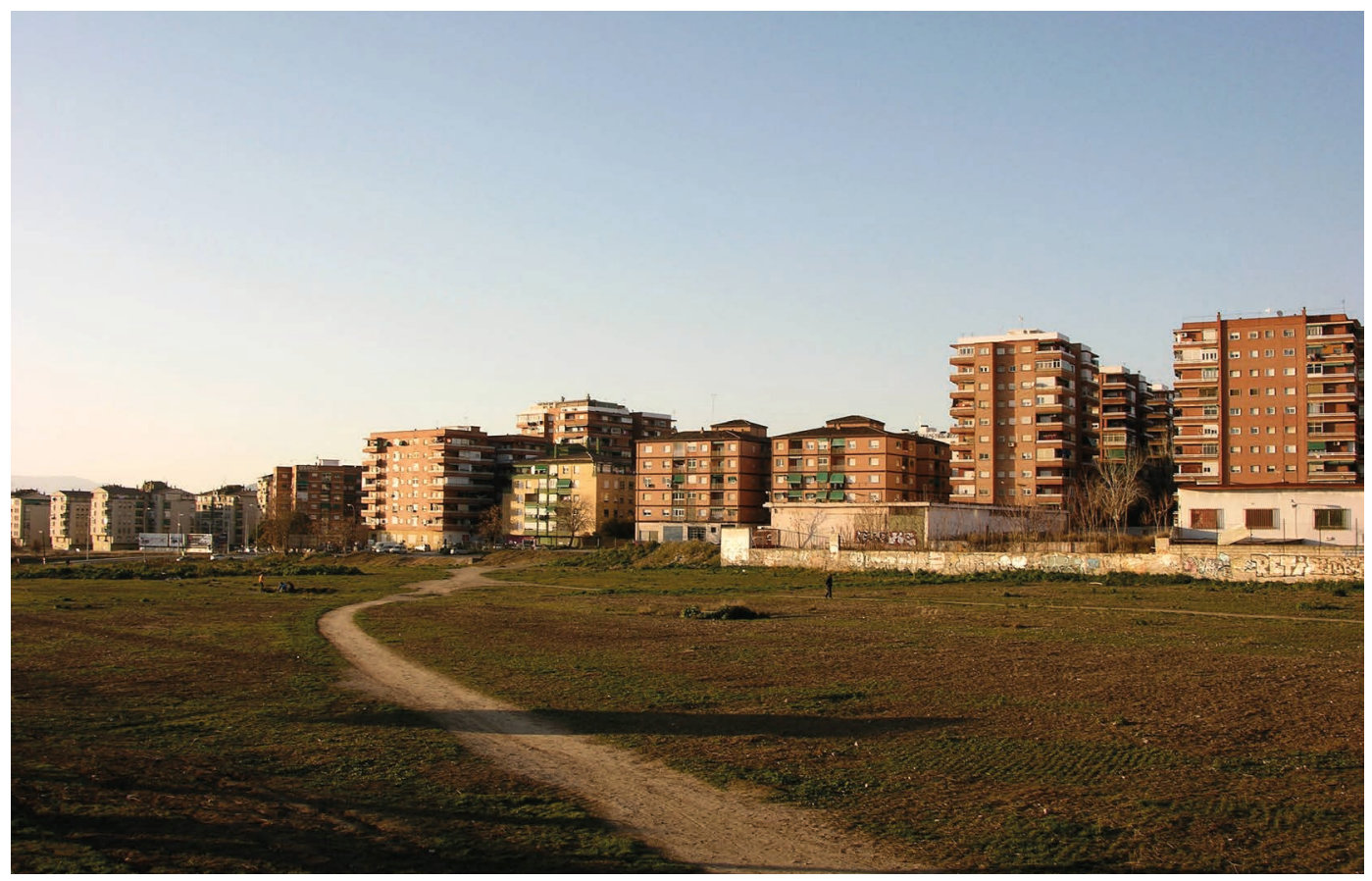

Fig. 3 - Exterior image of a working-class district in Granada (Spain) seen from an open terrain vague next to the railway. Inhabitants spontaneously use the expectant land for recreation, pet walks, sports, and gatherings due to the high density and low urban quality of the built area (author copyrights).

ly orientated, and overlooking low-quality urban spaces. Thus, many of these windows are veiled, and numerous balconies appear illegally closed or converted into linear storages on the façades. Also, flat roofs of collective housing buildings seem almost invariably forgotten and relegated to occasional maintenance of technical installations. These elements have frequently been neglected by standardized architectural design due to their low monetary profitability. An ambitious urban housing refurbishment strategy could involve upgrading these terraces, access galleries, porticoes, or rooftops, converting them into winter gardens, urban orchards, private or communal open spaces. In this sense, landscape architecture can significantly contribute to making coherent, adaptative, and stimulating those transitions between inside and outside in existing and projected residential areas. A fruitful collaboration between architects and landscape ar- chitects would raise environmental design concerns among the former; but, above all, it would enhance residents' quality of life by containing depopulation, enriching the experience of anodyne architecture, and contributing to the 'interior urban landscape' character, as discussed next.

\section{Streetscapes or 'Interior Urban Landscapes'}

Secondly, it seems necessary to examine the 'interior urban landscape' (Zoido Naranjo, 2012) of city neighborhoods, as experienced from the street. The urban area around the home is usually the most frequented, even more during perimeter closures such as those lived in 2020. The 'interior urban landscape' of the quarter is directly related to individual and group identity. Its appreciation or aversion strongly influences the overall townscape interpretation through an unconscious process of extrapolation or mental synecdoche. 

itage and shared habitat. Reducing urban landscape to mere space or land value has led to chaotic agglomerations of buildings and housing developments that juxtapose with hardly any dialogue. The COVID-19 pandemic has particularly revealed the unacceptable imbalance between different urban districts, some lacking proportional and well-conceived open spaces, attractive sequences, functional diversity, committed buildings, enough vegetation, and even the desirable sunlight and airing, while others - habitually those inhabited by people with the highest incomes - have them in abundance (Alraouf, 2021). Tacitly, a combined process of landscape aestheticization (Lipovetsky and Serroy, [2013] 2015) and elitization seems to have been accomplished, producing a clear hierarchy and social segregation of the urban space. While, in elite residential areas, the landscape is exploited as a decorative background and nature treated as a cosmetic application, inhabitants at the outlying neighborhoods frequently use terrain vagues (Solà-Morales, 1995), abandoned agricultural lands, or vacant plots for gatherings, sports, pet walks, and relaxation (Fig. 3). Nevertheless, these spaces seem mostly doomed to densification with further constructions, a process that will unconsciously continue to
The debate on landscape as a commons and the right to inhabit a dignified, salutary, and ethical environment has intensified in the past years, bringing into it questions of equality, holistic planning, naturalization of urban life, and democratization of territorial heritage (Asociación de Geógrafos Españoles, 2006; Castiglioni et al., 2015; Egoz et al., 2016; Cerber and Hess, 2017; Haase et al., 2017; Checa-Artasu, 2019; Rueda-Palenzuela, 2019). The global sanitary situation suggests more efforts should be made to rebalance the quality of life of different urban districts avoiding gentrification. Architecture, landscape architecture, and urban planning must take on this challenge, joining forces and overcoming conventional compartmentalization. It may be the right time to recall the five attributes synthesized by Jack L. Nasar for the quality of an urban landscape: presence of nature (naturalness), good maintenance (upkeep/civities), visual openness, historical significance, and perceptive order (1990, 1998). Additionally, Kevin Thwaites has listed the experiential qualities that should be targeted in any neighborhood: significance and value, orientation, and sense of identity (2001). These and other features should not be understood as a 'recipe book' for trivial and disjointed applications; instead, they could form part of an integrated 'interior urban landscape' project for each neighborhood that meets its specificities. Such a document would provide a frame of reference to rethink building typologies, densities, and heights; create open spaces according to site potentials (McHargh, 1969); re-naturalize degraded areas; recover distinctive perspectives, and harness the power of design to make residential areas more legible (Lynch, 1960), stimulating and pedestrian-friendly.

Within this planning framework, regarding the mass, policies should be included to ensure that building replacements contribute to a consistent improvement of the urban district. The mechanical substitution of edifices by other equivalents 


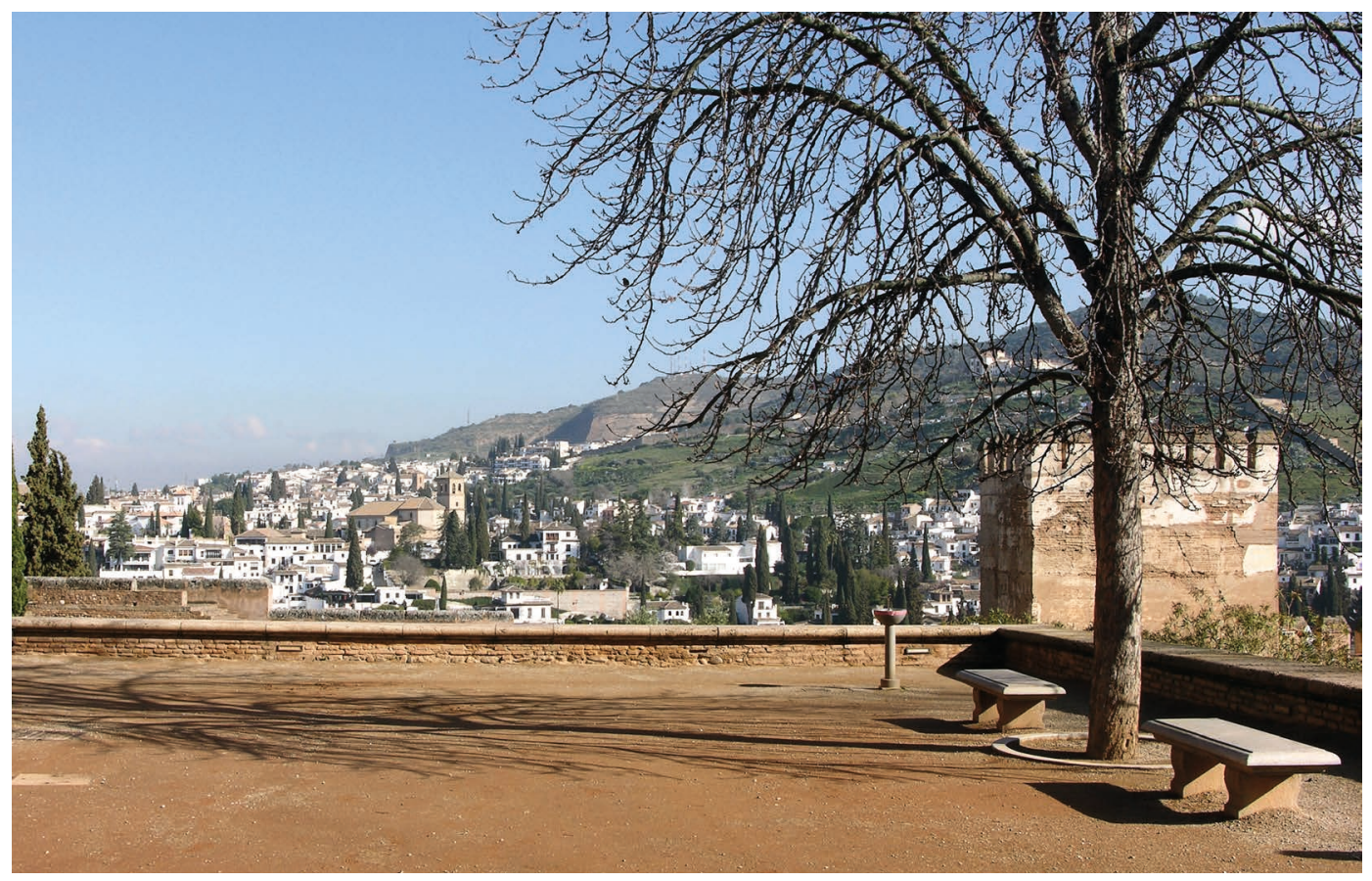

Fig. 4 - A chance to rediscover the landscape of Granada from an empty Alhambra in the absence of tourists (author copyrights).

that only differ from the previous ones in compliance with current construction regulations should be avoided, as these operations evade commitment to the urban landscape. Building ordinances, like other sectorial or specific provisions, should be integrated into such an 'interior urban landscape' strategy, as they only rule some of the elements of the urban environment. Moreover, landscape design seems critical to re-qualify 'interior urban landscapes' by affirming voids as indispensable parts of the urban ecosystem rather than remaining plots waiting to be occupied. Urban voids must come to be understood as 'full' of other contents just as essential as those hosted by buildings for the proper functioning of the city. By integrating natural processes, humans and non-humans, adaptability, indeterminacy, and change, open spaces should become a structural part of the town and a reservoir for the future: a true 'green infrastructure' (Batlle, 2013).
In this sense, street redesigning can favor not only the naturalization of neighborhoods and the creation of qualified, walkable public areas but also the liberation of the necessary space for other flows that were already booming before the pandemic and have rapidly intensified, such as those of micro-mobility devices (bicycles, e-scooters, and others) and delivery vehicles (Lai et al., 2020). Cities on all continents are now implementing what has been called 'tactical urbanism': a series of low-cost temporary interventions to pacify some urban sections and put them at the service of pedestrians and residents (Blanchar, 2020; Gillis and Thompson, 2020). However, these commendable initiatives should not remain ephemeral and isolated actions but evolve into permanent and self-sustainable solutions, as part of the proposed 'interior urban landscape' plans or similar strategies. Only holistic planning can provide a social guarantee for the medium and long-term improvement of streetscapes. 


\section{Cityscapes or 'Exterior Urban Landscapes'}

Thirdly, we should consider the global cityscape, as experienced from internal or external vantage points, from perimeter terrains vagues, and the main access routes: what Florencio Zoido calls the 'exterior urban landscape' (2012). According to Norberg-Schulz, inhabiting - in its full human implications - presupposes identification with the landscape (1979, p. 20). Distinctive urban prospects and city silhouettes act as condensers of memories and identities, generating attachment to the location (Nogué, 2007). This type of landscape experience also provides a clear understanding of the city in its territorial framework, with the exchanges and tensions it creates. Observing architecture, one can equally recognize the dominant activities, the spatial distribution of economic powers, or the predominance of certain historical times over others. In this regard, experiencing cityscapes encourages reflection on the coevolution (Magnaghi, 2000) of a society and its natural environment and fosters the sense of place (Sánchez del Árbol et al., 2002). We can, therefore, characterize this modality of landscape experience as external, panoramic, comprehensive, public, and receptive.

This global perception has not always been possible during the pandemic due to the intermittent lockdowns, and perhaps precisely for this reason, it has been associated with free time, walk and exercise: a revitalizing break from the monotonous routine. It has also allowed a re-encounter with roots and collective identity in this harsh situation. Many citizens have rediscovered their hometowns and watched them with new eyes, now that tourists have vanished and the inertial escape to remote 'paradises' has been prohibited (Fig. 4). If previously 'exterior urban landscapes' were, to a great extent, abandoned to the real estate laissez-fare or assumed as 'postcards' or 'showcases' for tourism and entrepreneurial investment (McLaren and
2006; Muñoz Ramírez, 2008, p. 57), now city fringes, skylines, and urban façades are being exceptionally perceived by lots of attentive locals that before just passed by with their minds absent. Megalomaniac developments in progress, closed or empty touristic facilities, paralyzed construction works, abandoned buildings, or vacant lands are being observed and publicly discussed. There is a unique collective debate, with citizens significantly involved due to the eye-opening experience of the pandemic. In Granada, a segment of a future green belt has suddenly begun to be planted, public spaces on the edges of the highway - which have been vacant lands for decades - have started to be outlined, and several social groups are demanding the reuse of an abandoned factory on the outskirts for cultural and scientific uses. In this context, some pending questions arise: How should urban limits be characterized? Should they aim to be 'read' or to be 'lived' (Lefebvre, 1974; Corner, 1999)? What kind of buildings or infrastructures should define urban edges? To which public should they be oriented? How can former industrial complexes or disused agricultural land be integrated into the metropolitan dynamic? Is it acceptable that private constructions overshadow mountainous profiles or emblematic landmarks? (Kostof, 1991) Are high-rise buildings any more advisable? These and other reflections seem now pertinent.

What is clear is that the pandemic should serve as a reminder that cityscapes must be conceived and designed first and foremost for their own inhabitants: they should be dynamic realities responding to the processual, perceptual, and imaginative aspects intertwined in the fascinating ecology of the city. Understanding and refining this urban ecology should be one of the main objectives for the post-COVID architect and planner, and, once again, landscape architecture can light the path. Thinking of the town as a landscape (or as part of a larger one) necessarily leads to a broadening of horizons of the ordinary 
building and urban design processes, moving the focus from the creation of solipsistic objects, the compliance with coefficients, and the satisfaction of economic interests to the integrated conception of spatial solutions for that complex concentration of flows, energies, and thoughts that is the city (Waldheim, 2006; Waldheim, 2016). Similarly, recognizing the city as a landscape demands a firm commitment to reconstruct and regenerate territorial identities, alarmingly weakened in some localities due to abusive land practices. Addressing these challenges requires a phased, transdisciplinary action that could take a 'city-landscape' plan as a guide. The European Landscape Convention established the need to 'integrate' landscape into urban policies; however, research suggests that it is precisely the urban landscape that must become their frame and ultimate target, given its comprehensive and all-encompassing condition. A 'city-landscape' plan should assemble the suggested 'interior urban landscape' projects at a district level and establish the 'city-landscape' model to achieve in the coming decades, not forgetting to resolve the transition between the urban ecosystem and other adjacent ecologies (McHarg, 1969; Magnaghi, 2000; Zoido Naranjo, 2002; Steiner, 2011; Batlle, 2013; De las Rivas Sanz, 2013). The situations caused by COVID-19 have come to confirm what had been pointed out for years: that 21st-century cities cannot be devoid of landscape planning.

\section{Conclusions}

The motivation for writing these lines was the realization, during the COVID-19 pandemic, that professionals involved in city shaping still have a lot to learn concerning the urban landscape. It is manifest that most of the townscapes we inhabit have not yet reached the desirable quality. Their experience shows social inequalities, imbalances between pedestrians and other means of transport, environmental unsustainability, perceptive and spatial conflicts, or identity crisis.
As diverse as they may seem, many of these problems have a common root: the outdated and anachronistic approaches to the urban landscape. At least in Spain, design and planning processes - conditioned by legislative frameworks, developers' interests, or administrative procedures - clearly privilege the mass over the void (the void understood in an implicitly negative way as the unbuilt, nonlucrative, undeveloped, unproductive, informal) and tend to ignore the true scope of 'landscape' as defined by the European Landscape Convention. There is also a striking lack of communication and coordination between the different actors that configure the built environment. The consequences are appreciable in exterior urban images, at street level, and from inside the most conventional buildings. The pandemic has only proclaimed loudly and through dramatic situations what was known but so far tolerated and assumed as inevitable.

However, the parenthesis COVID-19 has opened in urban life could become, if analyzed critically, a point of inflection. Citizens are rapidly acknowledging the qualitative aspects of architecture and landscape and their joint repercussions on well-being. They now require qualified, healthy, and sustainable life experiences offering a range of situations between indoors and outdoors, between privacy and sociability, between introspection and territorial identification. Hopefully, when the pandemic is over, they will continue to be more demanding regarding the quality of their homes, neighborhoods, and cityscapes. Design and planning practitioners should react to this feedback from the population and update their work schemes, taking the opportunity to train and acquaint themselves with landscape matters. In this sense, landscape architecture represents a discipline from which a valuable apprenticeship can be extracted. In particular, landscape architecture successfully integrates a holistic conception of 'Iandscape' as well as the notions of time, motion, 
adaptability, resilience, ecology, or indeterminacy as project inputs. The acceptance of these variables, with which other professions are not yet too familiar, would make it possible to advance from the ideation parameters traditionally applied to buildings and cities (visual, two-dimensional, and static) towards a more comprehensive landscape awareness. Enriching their conception of landscape would allow professionals to dialogue fruitfully across disciplines and detect the correspondences between forms, materials, and processes occurring in the urban environment. Learning from landscape architecture can also reduce the pressures habitually received from other sectors with their machinist, economistic, or commercial approaches, which only exacerbate conventional myopia concerning the urban landscape. The quality of the built environment, recently characterized as a balanced combination of aesthetics, habitability, environment-friendliness, accessibility-mobility, inclusiveness, distinctiveness, sense of place, affordability, and integration into the surrounding environment (Architects' Council of Europe, 2019), must become the main objective of new conscious architectural projects. The truth is that the European panorama is shifting decidedly towards a holistic consideration of landscape from which those concerned with city construction should not remain on the sidelines.
Finally, administrations have a chance to reflect on the urban and housing policies they have been applying so far. The exceptional situation has increased power and confidence in the public sector (Kunzmann, 2020), so paradigm shifts seem now more feasible than in periods of thoughtless prosperity. In particular, it is urgent to rethink and re-plan cities and their neighborhoods in terms of landscape, not only in response to the pandemic but also to address the climate emergency and the 'new poverties' (Magnaghi, 2000) derived from the mercantile exploitation of territorial resources. For this purpose, we have suggested the transdisciplinary elaboration of 'interior urban landscape' projects interwoven into a holistic 'city-landscape' plan, but there may be other strategies. At present, a national law on the quality of architecture and the built environment is being drafted in Spain, raising high expectations (Ministerio de Transportes, Movilidad y Agenda Urbana, 2020). A responsible public posture seems decisive to avoid a rapid depopulation and degradation of significant urban sectors, given that suburban enclaves are now showing renewed attractiveness. The commodification wave of bucolic landscapes that begins to arise in reaction to the pandemic must be counteracted with a determined upgrading of existing towns. In all probability, the solution to the current urban crisis does not lie in 
consuming more virgin soil or urbanizing the countryside, but in improving the quality of life in cities. The town that decides to learn from COVID-19 will be a naturalized, meaningful urban ecosystem, designed collaboratively between architects, urban planners, landscape architects, and other specialists in the urban phenomenon. A network of green corridors and multifunctional public spaces will shape the urban structure, allowing walking through, running, or encircling the built area by bicycle or micro-mobility devices. It will be a city of proximity and short distances, with accessible, effective, and environmentally-friendly public transport for longer journeys. Streets will be bright and airy with the minimum surface devoted to motor vehicles and only in the widest arteries, favoring air quality, social interaction, and rest for residents. Street parking will be strictly limited to delivery vehicles, and edifices will include common ground-floor spaces to store bicycles or e-scooters. New buildings will consciously dialogue with each other and respond to local conditions, defining the neighborhood ambiance and contributing to a coherent characterization of the open spaces. Architectural works will be increasingly flexible and perfectible, including a conscious degree of indeterminacy, varied spatial configurations, and generous gradients of privacy (personal spaces, shared spaces, neighborhood spaces, social spaces).
Homes will be composed of interior and exterior rooms in similar proportion, with well-orientated living spaces that put their occupants in connection with qualified outdoor areas and the natural elements. As a result of its good functioning, the city will offer a legible structure and urban silhouette, characterized by the harmonious interweaving with the surrounding territory and some outstanding collective landmarks that respond to civic pride. Local miradors, exceptional sites, and vantage points offering a significant landscape experience will be public, well maintained, and open to locals free of charge. Citizens will share a deep sense of place and be actively engaged in neighborhood improvement and decision-making tasks. The flourishing, resilient, and self-sustainable post-COVID town seems to be none other than the 'city-landscape'. 
01

\section{Endnotes}

${ }^{1}$ I had the opportunity to collaborate in the campaign driven by the Monachil town council in May 2020, entitled Desde mi Ventana: Compartiendo Paisaje Durante la Cuarentena. The digital photobook produced with the contributions of the neighbors is available at <https://escalameo.com/read/00597947756a998d8b19c> (05/20).

\section{Acknowledgements}

The research carried on by the author is funded by the Training Programme for University Teaching Staff (FPU) of the Spanish Ministry of Universities (FPU16/02495).

\section{References}

Alraouf A. A. (in press), The 'new' normal or the 'forgotten' normal: contesting COVID-19 impact on contemporary architecture and urbanism, «Archnet-IJAR: International Journal of Architectural Research», n. ahead-of-print, <https://doi.org/10.1108/ARCH-10-2020-0249> (03/21).

Appleton J. 1975, The Experience of Landscape, John Wiley \& Sons, London.

Aranda J. L. 2020, El éxodo del coronavirus: de la ciudad al unifamiliar, "El País», <https://elpais.com/economia/2020-12-12/el-exodo-del-coronavirus-de-la-ciudad-al-unifamiliar.html> (03/21).

Architects' Council of Europe, 2019, Achieving Quality in the Built Environment, Innsbruck.

Asociación de Geógrafos Españoles, 2006, Manifiesto por una nueva cultura del territorio, <https://www.geografos. org/wp-content/uploads/2013/07/interes_nuevacultura_manifiesto-por-una-nueva-cultura-del-territorio-d5. $p d f>(07 / 20)$.

Bachelard G. 2013, La poética del espacio, E. de Champourcin (trans.), Fondo de Cultura Económica, Mexico City [First published 1957].
Barnés H. G., Sanz E. 2020, “Que la próxima pandemia nos pille con jardin": el covid-19 nos empuja a la periferia, «El Confidencial», <https://www.elconfidencial.com/vivienda/2020-05-07/coronavirus-empuja-periferia-vivienda_2582780/> (03/21).

Batlle, E. 2013, El jardin de la metrópoli: del paisaje romántico al espacio libre para una ciudad sostenible, Gustavo Gili, Barcelona.

Batty M. 2020, The Coronavirus crisis: What will the post-pandemic city look like?, «EPB: Urban Analytics and City Science», vol. 47, n. 4, pp. 547-552, <https://doi. org/10.1177/2399808320926912> (03/21).

Blanchar C. 2020, Barcelona: la reconquista táctica del asfalto, «El País Semanal», <https://elpais.com/ elpais/2020/11/02/eps/1604332524_619918.html? rel=mas $>(03 / 21)$.

Castiglioni B. et al. (eds) 2015, Landscape as Mediator, Landscape as Commons: International Perspectives on Landscape Research, Coop. Libraria Editrice Università di Padova, Padova.

Checa-Artasu M. M. 2019, ¿Es el paisaje un bien común? Unas notas, «Dearq», n. 24, pp. 60-67, <https://doi. org/10.18389/dearq24.2019.05> (03/21).

Corner J. 1999, Eidetic Operations and New Landscapes, in J. Corner (ed.), Recovering Landscape: Essays in Contemporary Landscape Architecture, Princeton Architectural Press, New York, pp. 153-169.

Council of Europe, 2000, European Landscape Convention, Florence.

Cuerdo-Vilches T. et al. 2020, A Mixed Approach on Resilience of Spanish Dwellings and Households during COVID-19 Lockdown, "Sustainability», vol. 12, n. 23 , <https://doi.org/10.3390/su122310198> (12/20). 
Cullen G. 1981, El paisaje urbano. Tratado de estética urbanistica, J. M. Aymamí (trans.), Blume, Barcelona [First published 1961].

De las Rivas Sanz J. L. 2013, Hacia la ciudad paisaje. Regeneración de la forma urbana desde la naturaleza, «Urban», n. 5, pp. 79-93.

Eckbo G. 1983, Is Landscape Architecture?, «Landscape Architecture Magazine», vol. 73, n. 3, pp. 64-65.

Egoz S. et al. (eds) 2016, The Right to Landscape: Contesting Landscape and Human Rights, Routledge, New York [First published 2011].

European Ministers of Culture, 2018, Davos Declaration: Towards a high-quality Baukultur for Europe, Davos.

Ferrás Sexto C. 2020, Ciudades dispersas y aldeas virtuales en la postpandemia del COVID-19, «Finisterra», vol. 55, n. 115, pp. 243-248, <https://doi.org/10.18055/Finis20279> (03/21).

Fitch J. M. 1965, The Aesthetics of Function, «Annals of the New York Academy of Sciences», vol. 128, n. 2, pp. 706714, <https://doi.org/10.1111/j.1749-6632.1965.tb11687.x> (03/21).

Gehl J. 2006, La humanización del espacio urbano: la vida social entre los edificios, M. T. Valcarce (trans.), Reverté, Barcelona [First published 1971].

Gerber J. D., Hess G. 2017, From Landscape Resources to Landscape Commons: Focusing on the Non-Utility Values of Landscape, «International Journal of the Commons», vol. 11, n. 2, pp. 708-732, <http://doi.org/10.18352/ijc.745> (03/21).

Gillis J., Thompson H. 2020, Take Back the Streets from the Automobile, «The New York Times», <https://www. nytimes.com/2020/06/20/opinion/pandemic-automobile-cities.html> (03/21).
Haase D. et al. 2017, Greening cities - To be socially inclusive? About the alleged paradox of society and ecology in cities, «Habitat International», n. 64, pp. 41-48, <https:// doi.org/10.1016/j.habitatint.2017.04.005> (03/21).

Heidegger M. 1994, Construir, Habitar, Pensar, in Conferencias y artículos, E. Barjau (trans.), Serbal, Barcelona [First published 1951].

Hermann I., Paris C. M. 2020, Digital Nomadism: the nexus of remote working and travel mobility, «Information Technology and Tourism», vol. 22, n. 3, pp. 329-334, <https:// doi.org/10.1007/s40558-020-00188-w> (03/21).

Holl S. 2011, Cuestiones de percepción. Fenomenología de la arquitectura, M. Puente (trans.), Gustavo Gili, Barcelona [First published 1994].

Kaika M., Thielen K. 2006, Form follows power: A genealogy of urban shrines, «City», vol. 10, n. 1, pp. 59-69, <https:// doi.org/10.1080/13604810600594647> (03/21).

Kaplan R. 1983, The Role of Nature in the Urban Context, in Behavior and the Natural Environment, in I. Altman, J. F. Wohlwill (eds), Plenum Press, New York - London, pp. 127-161.

Kaplan R. 2001, The Nature of the View from Home: Psychological Benefits, «Environment and Behavior», vol. 33, n. 4, pp. 507-542, <https://doi.org/10.1177\% 2F00139160121973115> (03/21).

Kaplan R., Kaplan S. 1989, The Experience of Nature: A Psychological Perspective, Cambridge University Press, Cambridge.

Kearney A. R. 2006, Residential Development Patterns and Neighborhood Satisfaction: Impacts of Density and Nearby Nature, «Environment and Behavior», vol. 38, n. 1, pp. 112-139, <https://doi.org/10.1177/0013916505277607> (03/21). 
01
Kostof S. 1991, The City Shaped: Urban Patterns and Meanings Through History, Thames and Hudson, London.

Kunzmann K. R. 2020, Smart Cities After Covid-19: Ten Narratives, «disP - The Planning Review», vol. 56, n. 2, pp. 20-31, <https://doi.org/10.1080/02513625.2020.1794120 $>(03 / 21)$.

Lai S. et al. 2020, Covid-19 and Spatial Planning, «TeMA: Journal of Land Use, Mobility and Environment», Special Issue: Covid-19 vs City-20: Scenarios, Insights, Reasoning and Research, pp. 231-246, <https://doi. org/10.6092/1970-9870/6846> (03/21).

Lefebvre H. 1974, La production de l'espace, Éditions Anthropos, Paris.

Lewis P. F. 1979, Axioms for reading the landscape, in D. W. Meinig (ed.), The Interpretation of Ordinary Landscapes: Geographical Essays, Oxford University Press, Oxford, pp. 11-32.

Lipovetsky G., SerroyJ. 2015, La estetización del mundo: vivir en la época del capitalismo artístico, A. P. Moya (trans.), Anagrama, Barcelona [First published 2013].

Lynch K. 1960, The Image of the City, MIT Press, Cambridge - London.

Magnaghi A. 2000, Il progetto locale, Bollati Boringhieri, Torino.

Markus T. A. 1967, The Function of Windows - A Reappraisal, «Building Science», vol. 2, n. 2, pp. 97-121, <https://doi. org/10.1016/0007-3628\%2867\%2990012-6> (04/20).

McHarg I. 1969, Design with Nature, Natural History Press, New York.

McLaren B., Lasansky D. M. (eds) 2006, Arquitectura y turismo: percepción, representación y lugar, M. J. Rivas Centeno (trans.), Gustavo Gili, Barcelona [First published 2004].
Merleau-Ponty M. 1993, Fenomenología de la percepción, J. Cabanes (trans.), Planeta-Agostini, Barcelona [First published 1945].

Ministerio de Transportes, Movilidad y Agenda Urbana, 2020, Consulta pública previa sobre el anteproyecto de Ley de arquitectura y calidad del entorno construido, <https:// www.mitma.gob.es/el-ministerio/buscador-participacion-publica/anteproyecto-de-ley-de-arquitectura-y-calidad-del-entorno-construido> (07/20).

Mirza L. 2015, Windowscapes: A Study of Landscape Preferences in an Urban Situation. Unpublished PhD dissertation, University of Auckland.

Muñoz Ramírez F. 2008, Urbanalización: paisajes comunes, lugares globales, Gustavo Gili, Barcelona.

Nasar J. L. 1990, The Evaluative Image of the City, "Journal of the American Planning Association», vol. 56, n. 1, pp. 41-53, <https://doi.org/10.1080/01944369008975742> (05/20).

Nasar J. L. 1998, The Evaluative Image of the City, Sage Publications, Thousand Oaks.

Neutra R. J. 1955, La arquitectura como factor humano, Instituto Técnico de la Construcción y del Cemento, Madrid.

Nogué J. 2007, Territorios sin discurso, paisajes sin imaginario. Retos y dilemas, «Ería. Revista cuatrimestral de Geografía», n. 73-74, pp. 373-382.

Norberg-Schulz C. 1975, Existencia, espacio y arquitectura, A. Margarit (trans.), Blume, Barcelona [First published 1971]. Norberg-Schulz C. 1979, Genius Loci: Towards a Phenomenology of Architecture, Rizzoli, New York.

Putinja I. 2021, Croatia Wants Tourists to Move There. These People Are Doing Just That, «CNN Travel», <https:// edition.cnn.com/travel/article/croatia-digital-nomads/ index.html> (03/21). 
Relph E. 1976, Place and Placelessness, Pion, London.

Rueda-Palenzuela S. 2019, El Urbanismo Ecosistémico, «Ciudad y Territorio. Estudios Territoriales», vol. 51, n. 202, pp. 723-752.

Sánchez del Árbol M. Á. et al. 2002, Bases para el establecimiento de una red de miradores en Andalucía, in Paisaje y ordenación del territorio, Consejería de Obras Públicas y Transportes, Junta de Andalucía, Fundación Duques de Soria, Sevilla, pp. 255-268.

Solà-Morales I. 1995, Terrain Vague, in C. C. Davidson (ed.), Anyplace, MIT Press, Cambridge, pp. 118-123.

Steiner F. 2011, Landscape ecological urbanism: Origins and trajectories, "Landscape and Urban Planning», vol. 100, n. 4, pp. 333-337, <https://doi.org/10.1016/j.landurbplan.2011.01.020>(03/21).

Thayer, R. L. 1989, The Experience of Sustainable Landscapes, «Landscape Journal», vol. 8, n. 2, pp. 101-10, <https://doi.org/10.3368/lj.8.2.101> (05/21).

Thwaites K. 2001, Experiential Landscape Place: An Exploration of Space and Experience in Neighbourhood Landscape Architecture, "Landscape Research», vol. 26, n. 3, pp. 245-255, <https://doi. org/10.1080/01426390120068927> (12/20).

Waldheim C. (ed.) 2006, The Landscape Urbanism Reader, Princeton Architectural Press, New York.

Waldheim C. 2016, Landscape as Urbanism, Princeton University Press, New York.

Zoido Naranjo F. 2002, El paisaje y su utilidad para la ordenación del territorio, in Paisaje y ordenación del territorio, Consejería de Obras Públicas y Transportes, Junta de Andalucía, Fundación Duques de Soria, Sevilla, pp. 21-32.
Zoido Naranjo F. 2012, Paisaje urbano. Aportaciones para la definición de un marco teórico, conceptual y metodológico, in C. Delgado Viñas et al. (eds), Ciudades y paisajes urbanos en el siglo XXI, Librería Estudio, Santander, pp. 13-92. 